1299 | Jurnal Idea Hukum

Vol. 5 No. 1 Maret 2019

Magister Hukum Fakultas Hukum Universitas Jenderal Soedirman

\title{
PERTANGGUNGJAWABAN HUKUM TERHADAP PENYALAHGUNAAN WEWENANG OLEH PENGGUNA ANGGARAN DALAM PENGADAAN BARANG DI KABUPATEN BREBES \\ Oleh: Suwarni ${ }^{1}$
}

Abstract

The implementation of a transparent government in the implementation of project tenders is an important issue that needs to be responded to immediately by the local government. This study aims to find out and analyze the abuse of authority by Budget Users in the procurement of goods in Brebes Regency. In addition, it is also to analyze the legal accountability of Budget Users against abuse of authority in the procurement of goods in Brebes Regency. The study uses a normative juridical approach, with secondary data sources and quantitative analysis.

The results showed that, Abuse of authority by Budget Users in the procurement of goods in Brebes Regency was a category of abuse of authority / beyond authority (Detournement de Pouvoir) with traits beyond the tenure or deadline for authorization, beyond the territorial limits of authority; and / or contrary to the provisions of the legislation. The act of Herman Adi AW as a Budget User is an act that is contrary to the provisions of the laws and regulations that are specifically regulated in Article 5 of Presidential Regulation Number 54 of 2010 along with its amendments, especially the principles of transparency, competition and accountability.

The Budget User's legal responsibility for abuse of authority in the procurement of goods in Brebes Regency can be subject to criminal sanctions, namely that criminal responsibility for abuse of authority is regulated in Article 3 of the Corruption Act. Herman Adi Aw as a budget user who is proven to be corrupt with a prison sentence of 1 (one) year and 6 (six) months, as well as a fine of Rp. 50,000,000.00 (fifty million rupiah). Based on civil liability Herman Adi Aw as the Budget User is obliged to return compensation. Based on the administrative aspect, the Brebes Regency Government issued the Brebes Regent Decree No. 887/080 of 2014 as of January 24, 2014 temporarily suspending the position of Herman Adi AW in his position as the Head of the Industry Office.

Keywords: liability, abuse of authorit,budget's utilization

\section{ABSTRAK}

Penyelenggaraan pemerintahan yang transparan dalam pelaksanaan tender proyek, merupakan isu penting yang perlu segera direspon pemerintah daerah. Penelitian ini bertujuan untuk mengetahui dan menganalisis penyalahgunaan wewenang yang dilakukan Pengguna Anggaran dalam pengadaan barang di Kabupaten Brebes. Selain itu juga untuk menganalisis pertanggungjawaban hukum Pengguna Anggaran terhadap penyalahgunaan wewenang dalam pengadaan barang di Kabupaten Brebes. Penelitian menggunakan metode pendekatan yuridis normatif, dengan sumber data sekunder serta analisis kuantitatif.

Hasil penelitian menunjukan bahwa, Penyalahgunaan wewenang yang dilakukan Pengguna Anggaran dalam pengadaan barang di Kabupaten Brebes merupakan kategori penyalahgunaan wewenang/ melampaui wewenang (Detournement de Pouvoir) dengan ciri-ciri melampaui masa jabatan atau batas waktu berlakunya Wewenang, melampaui batas wilayah berlakunya Wewenang; dan/atau bertentangan dengan ketentuan peraturan perundang-undangan. Perbuatan Herman Adi AW sebagai Pengguna Anggaran merupakan perbuatan yang bertentangan dengan ketentuan peraturan perundang-undangan yang secara spesifik diatur dalam Pasal 5 Perpres Nomor 54 Tahun 2010 beserta Perubahannya khususnya prinsip transparan, bersaing dan akuntabel.

\footnotetext{
${ }^{1}$ Pemerintah Daerah Kabupaten Brebes, Jawa Tengah, mochbee@gmail.com
} 
Pertanggungjawaban hukum Pengguna Anggaran terhadap penyalahgunaan wewenang dalam pengadaan barang di Kabupaten Brebes dapat dikenakan sanksi Pidana yaitu pertanggungjawaban pidana penyalahgunaan wewenang diatur dalam Pasal 3 Undang-Undang Tindak Pidana Korupsi. Herman Adi Aw selaku Pengguna anggaran yang terbukti melakukan korupsi dengan pidana penjara selama 1 (satu) tahun dan 6 (enam) bulan, serta pidana denda sejumlah Rp. 50.000.000,00 (lima puluh juta rupiah). Berdasarkan pertanggungjawaban perdata Herman Adi Aw selaku Pengguna Anggaran wajib mengembalikan ganti kerugian. Berdasarkan segi administrasi, Pemerintah Kabupaten Brebes mengeluarkan Surat Keputusan Bupati Brebes No 887/080 Tahun 2014 terhitung mulai 24 Januari 2014 memberhentikan sementara dari jabatan Herman Adi AW dalam Kedudukannya selaku Kepala Dinas Perindustrian.

Kata Kunci: Pertanggungjawaban, Penyalahgunaan Wewenang, Pengguna Anggaran

\section{A. Pendahuluan}

Korupsi terjadi karena adanya persekongkolan dalam tender proyek dan penyalahgunaan kekuasaan para penyelanggara negara. Oleh karena itu, penyelenggaraan pemerintahan yang transparan dalam pelaksanaan tender proyek, merupakan isu penting yang perlu segera direspon pemerintah daerah untuk mencapai tata pemerintahan yang baik sehingga akan terbentuk iklim kerjasama yang kondusif antara pemerintah dengan sektor swasta untuk meningkatkan investasi di daerah.

Berdasarkan pengalaman
tersebut, tentunya Pemerintah
Kabupaten Brebes tidak mau
mengulangi kesalahan yang sama, oleh
karena itu Pemerintah Kabupaten
Brebes selalu mengedepankan tata
pemerintahan yang baik dalam
penyelenggaraan pengadaan barang
dan jasa pemerintah. Hal ini ditandai
dengan penandatangan pakta integritas
dalam rangka membangun budaya no
korupsi oleh Gubernur, Kepala DPRD
Prov dan Kab/Kota, Bupati/ Walikota se

Jawa Tengah dan penandatangan Pakta Integritas seluruh Kepala OPD Kabupaten Brebes yang diketahui oleh Bupati dilaksanakan setiap tahun pada saat pembagian DPA.

Penerapan tata pemerintahan yang baik dalam pengadaan barang untuk membangun daerah tidaklah mudah. Terkadang penerapannya masih terdapat kendala yang dihadapi Pemerintah Kabupaten Brebes dalam rangka penerapan tata pemerintahan yang baik. Oleh karena itu perlu kajian ilmiah mengenai pertanggungjawaban hukum Pengguna Anggaran terhadap penyalahgunaan wewenang dalam pengadaan barang guna memberikan evaluasi kepada Pemerintah Kabupaten Brebes.

\section{B. Rumusan Masalah}

Berdasarkan latar belakang tersebut di atas maka dapat dirumuskan perumusan masalah sebagai berikut :

1. Bagaimanakah penyalahgunaan wewenang yang dilakukan Pengguna Anggaran dalam 
1301 | Jurnal Idea Hukum

Vol. 5 No. 1 Maret 2019

Magister Hukum Fakultas Hukum Universitas Jenderal Soedirman

pengadaan barangdi

Kabupaten Brebes?

2. Bagaimanakah

pertanggungjawaban

hukum

Pengguna

Anggaran

terhadap

penyalahgunaan

wewenang dalam

pengadaan barang di

Kabupaten Brebes?

\section{Metode Penelitian}

1. Metode: Yuridis Normatif Pendekatan

2. Spesifikasi : Preskriptif Penelitian

3. Jenis data : Data primer dan data sekunder

4. Metode : Studi kepustakaan

Pengambilan atau studi

Data dokumen.

5. Teknik : Teks naratif.

Penyajian

Data

6. Analisa Data : Kualitatif.

D. Hasil dan Pembahasan

1. Penyalahgunaan

Wewenang yang

Dilakukan Pengguna

Anggaran Dalam

Pengadaan Barang di

Kabupaten Brebes

Penyalahgunaan

wewenang lahir dari doktrin

hukum administrasi negara

(HAN). Penyalahgunaan

wewenang tidak dapat lepas dari

istilah aslinya (yang digunakan

oleh banyak literatur hukum nasional maupun détournement de pouvoir dalam literatur hukum berbahasa Inggris diserap dan diartikan sebagai misuse of power abuse of power Sebagaimana terminologi bahasanya tersebut, konsep ini pertama kali muncul di Prancis. Di Prancis, pejabat pemerintahan dinyatakan melanggar prinsip détournement de pouvoir, apabila dalam mengeluarkan keputusan atau melakukan tindakannya bertujuan untuk kepentingan pribadi si pejabat (termasuk keluarga atau rekannya), bukan untuk kepentingan atau ketertiban umum. $^{2}$

Menurut Philipus $\mathrm{M}$. Hadjon, dalam mengukur apakah telah terjadi penyalahgunaan wewenang, haruslah dibuktikan secara faktual bahwa pejabat telah menggunakan wewenangnya untuk tujuan lain. Terjadinya penyalahgunaan wewenang bukanlah karena suatu kealpaan. Penyalahgunaan wewenang dilakukan secara sadar yaitu mengalihkan tujuan yang telah diberikan kepada wewenangnya itu. Pengalihan tujuan didasarkan atas interest pribadi, baik untuk kepentingan

${ }^{2}$ John Bell, dkk, 1998, Principles of French Law, Oxford University Press, hal.184 
dirinya sendiri ataupun untuk orang lain. ${ }^{3}$

Tolok ukur terjadinya penyalahgunaan wewenang, harus didahului dengan adanya pembuktian secara faktual bahwa badan dan/atau pejabat pemerintahan telah menggunakan wewenangnya untuk tujuan lain. Namun, terjadinya penyalahgunaan wewenang bukanlah karena suatu kealpaan. Tindakan dan/atau keputusan tersebut dilakukan secara sadar, yaitu mengalihkan tujuan yang telah diberikan kepada wewenang itu. Pengalihan tujuan juga didasarkan atas kepentingan (interest) pribadi, baik yang sifatnya untuk diri sendiri maupun untuk orang lain. Dengan demikian, parameternya adalah untuk kepentingan umum.

Sebagai asas hukum, penyalahgunaan wewenang merupakan bagian dari asas hukum publik (khususnya HAN). Dalam HAN dikenal asas larangan penyalahgunaan wewenang, yang merupakan salah satu dari asas-asas umum pemerintahan yang baik (AAUPB). UU Nomor 9 Tahun 2004 menjadi dasar hukum

3 Philipus M. Hadjon, 2005 Pengantar Hukum Administrasi Negara Indonesia Penerbit Gajah Mada University Press Yogyakarta, hal. 26. bahwa AAUPB merupakan salah satu sarana pengujian keputusan dan/atau tindakan pemerintahan. Perkembangan AAUPB dalam area ilmu pengetahuan, ditemukan melalui discours (wacana ilmiah) dalam pandangan antagonistis antara Struycken dan Krabbe yang sama-sama dilatarbelakangi oleh kebencian mereka terhadap asas legalisme, meskipun di antara mereka terdapat perbedaan di dalam menemukan dasar bagi pentingnya kehadiran AAUPB tersebut. $^{4}$

Dalam literatur Indonesia, AAUPB sudah mulai dikenal sejak tahun 1953, melalui buku G.A. van Poelje yang diterjemahkan oleh B. Mang Reng Say, akan tetapi asas-asas tersebut tidak banyak memperoleh perhatian di lingkungan HAN Indonesia. Kemudian barulah sejak diperkenalkan oleh Crince de Roy dalam kuliahnya pada penataran Lanjutan HAN di tahun 1978 di Surabaya, AAUPB tersebut mulai banyak memperoleh perhatian di lingkungan HAN Indonesia. ${ }^{5}$

${ }^{4}$ SF. Marbun, 2001, Eksistensi AsasAsas Umum Penyelenggaraan Pemerintahan Yang Layak Dalam Menjelmakan Pemerintahan Yang Baik dan Bersih di Indonesia, Disertasi Unpad, Bandung, hal. 146

${ }^{5}$ Ibid., hal. 166 


\section{3 | Jurnal Idea Hukum}

Vol. 5 No. 1 Maret 2019

Magister Hukum Fakultas Hukum Universitas Jenderal Soedirman

Pasal 17 ayat (1) UU 30

Tahun 2014 tentang Administrasi

Pemerintahan menyatakan

bahwa, Badan dan/atau Pejabat

Pemerintahan dilarang

menyalahgunakan Wewenang.

Larangan penyalahgunaan

Wewenang meliputi larangan

melampaui Wewenang, larangan

mencampuradukkan Wewenang

dan larangan bertindak

sewenang-wenang yang dapat

dijabarkan sebagai berikut:

a. Larangan melampaui

Wewenang;

b. Larangan

Mencampuradukkan

Wewenang; dan/atau

c. Larangan Bertindak Sewenang-Wenang.

Ketentuan norma-norma tersebut hanya berupa patokan yang harus dipatuhi oleh badan dan/atau pejabat pemerintahan, sehingga perlu norma hukum lain (norma sekunder) yang mengatur tata cara penanggulangannya apabila norma primer tidak dipenuhi atau dipatuhi. Oleh karenanya berkaitan dengan ketentuan selanjutnya, yaitu Pasal 19 sampai dengan Pasal 21 UU AP.

Pasal 19 ayat (1) dan (2) di sini menentukan bahwa penyalahgunaan wewenang yang dilakukan pejabat pemerintahan itu sah atau tidak sah dan batal atau tidak batal berdasarkan

Putusan Pengadilan yang berkedudukan hukum tetap. Akan tetapi, sebelum adanya permohonan ke Pengadilan, menurut ketentuan Pasal 20 ayat (1) dan (2) tersebut, terlebih dahulu harus adanya hasil pengawasan dari aparat pengawasan intern pemerintah (APIP).

Herman Adi AW selaku Kepala Dinas Perindustrian dan Perdagangan Kabupaten Brebes telah membentuk kepanitiaan untuk pelaksanaan paket pekerjaan tersebut, sekitar bulan Januari-Februari 2011 Herman Adi AW selaku Kepala Dinas Perindustrian dan Perdagangan Kabupaten Brebes memanggil dan memerintahkan saksi LADZUARDI THIRIN selaku Kepala Seksi Bina Usaha Industri pada Dinas Perindustrian dan Perdagangan Kabupaten Brebes untuk melakukan pengadaan peralatan produksi industri kecil tahun 2011 di lingkup Dinas Perindustrian dan Perdagangan Kabupaten Brebes, dan meminta saksi LADZUARDI THIRIN untuk menggunakan $\mathrm{CV}$. milik $\mathrm{Ny}$. CHOSANAH, dan beberapa rekanan dengan maksud menggunakan bendera 


perusahaan/rekanan sebagai
formalitas pelaksanaan kegiatan
pengadaan tersebut.
Mekanisme pelaksanaan
paket kegiatan pengadaan
tersebut dilakukan dengan
Penunjukan Langsung dan
bersifat formalitas, dimana
Rekanan yang ditunjuk tidak
pernah mengajukan dokumen
penawaran ke Dinas
Perdagangan dan Perindustrian
Kabupaten Brebes, karena saksi
Ladzuardi Thirin telah membuat
sendiri dokumen penawaran atas
nama 12 Rekanan, dan membuat
seluruh administrasi dan
dokumen kegiatan pengadaan
peralatan industri kecil tersebut
antara lain berupa Kontrak, dan
Berita Acara Serah Terima
Pekerjaan.

Kelengkapan dokumen yang dibuatkan secara tidak benar oleh saksi Ladzuardi Thirin tersebut, selanjutnya dilakukan pencairan dana kegiatan dengan cara dilakukan transfer dana kegiatan ke rekening atas nama masing-masing perusahaan yang digunakan oleh saksi Ladzuardi Thirin sebagai formalitas kelengkapan kegiatan pengadaan. Selanjutnya masingmasing Rekanan melakukan pencairan atas dana yang masuk tersebut dan menyerahkannya kepada saksi Ladzuardi Thirin, selanjutnya sebagai imbalan terhadap penggunaan nama perusahaan/Rekanan, saksi Ladzuardi Thirin memberikan kompensasi berupa komisi (fee) kepada Rekanan sebesar 3\% dari nilai pekerjaan yang tercantum di dalam Kontrak Kerja Sama.

Berdasarkan jumlah ke-12 (dua belas) paket pekerjaan yang dilaksanakan sendiri oleh saksi Ladzuardi Thirin dengan nilai sebesar Rp.390.822.000,00 (tiga puluh sembilan juta delapan ratus dua puluh dua ribu rupiah), berdasarkan bukti-bukti pembelanjaan, saksi Ladzuardi Thirin hanya melakukan pembelian barang dan peralatan seharga Rp.169.524.333,00 (seratus enam puluh sembilan juta lima ratus dua puluh empat ribu) dengan kualitas barang di bawah standar.

\section{Ladzuardi}

Thirin

memperoleh keuntungan kurang lebih sebesar Rp.100.000.000,00 (seratus juta rupiah), yang dibagikan kepada Herman Adi AW selaku Kepala Dinas Perindustrian dan Perdagangan Kabupaten Brebes sebesar Rp.40.000.000,00 (empat puluh juta rupiah), kemudian Rp.20.000.000 (dua puluh juta rupiah) dibagikan kepada masing 
masing PPK sebesar Rp.1.500.000,00 (satu juta lima ratus ribu rupiah), Panitia Pengadaan Barang sebesar Rp.1.000.000,00 (satu juta rupiah), Panitia Pemeriksa Pekerjaan sebesar Rp.2.500.000,00 (dua juta lima ratus ribu rupiah), DPPKAD melalui Bendahara Karno sebesar Rp.3.500.000,00 (tiga juta lima ratus ribu rupiah), kepada saksi Karno sebesar Rp.1.000.000,00 (satu juta rupiah), untuk angkut dan BBM dalam rangka penyerahan di Desa Linggapura Kecamatan Tonjong Kabupaten Brebes sebesar Rp.5.000.000,00 (lima juta rupiah) dan untuk biaya operasional pada saat pelaksanaan dan konsumsi penyerahan barang sebesar Rp.5.500.000,00 (lima juta lima ratus ribu rupiah).

Perbuatan-perbuatan yang dilakukan oleh Herman Adi AW sebagaimana yang didakwakan oleh Penuntut Umum dalam Surat Dakwaannya, hanya dapat dilakukan oleh Herman Adi AW karena Herman Adi AW menduduki jabatan sebagai Kepala Dinas Perindustrian dan Perdagangan Kabupaten Brebes. Berdasarkan kewenangan kepada Herman Adi AW adalah karena Herman Adi AW menduduki

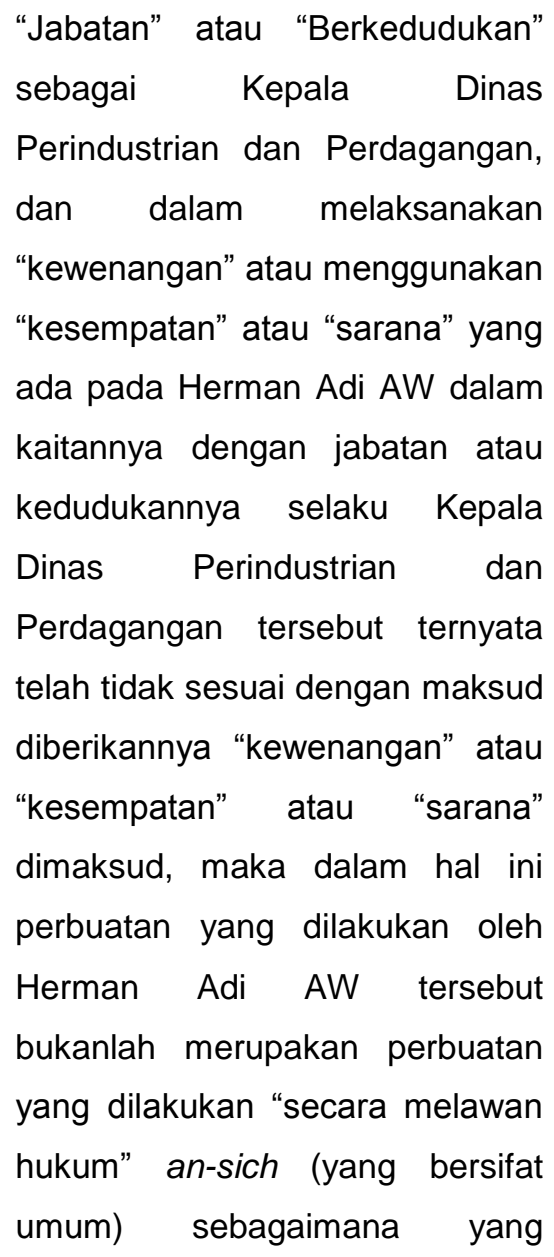
dikehendaki oleh ketentuan Pasal 2 ayat (1) Undang Undang Nomor 31 Tahun 1999 (seperti yang didakwakan dalam dakwaan Primair ini), melainkan merupakan perbuatan melawan hukum yang dilakukan dalam keadaan khusus karena perbuatan-perbuatan tersebut dilakukan oleh Herman Adi AW dalam "jabatan" atau "kedudukan" tertentu yaitu sebagai Kepala Dinas Perindustrian dan Perdagangan. Perbuatan yang dilakukan oleh Herman Adi AW dalam Kedudukannya selaku Kepala 


\begin{tabular}{|c|c|}
\hline $\begin{array}{l}\text { Dinas Perindustrian dan } \\
\text { Perdagangan yaitu berupa } \\
\text { memerintahkan saksi } \\
\text { Thirin uadzuardi } \\
\text { nama/menggunakan }\end{array}$ & $\begin{array}{l}\text { pengadaan dan tidak boleh } \\
\text { menunjuk lagi saksi Ladzuardi } \\
\text { Thirin untuk melaksanakan } \\
\text { pengadaan paket-paket pekerjaan } \\
\text { tersebut. }\end{array}$ \\
\hline $\begin{array}{l}\text { perusahaan/rekanan sebagai } \\
\text { formalitas pelaksanaan kegiatan, } \\
\text { memerintahkan saksi Ladzuardi } \\
\text { Thirin untuk meminjam uang } \\
\text { kepada saksi Silvia Pramudanti, } \\
\text { memerintahkan saksi Ladzuardi } \\
\text { Thirin untuk meminjam uang } \\
\text { kepada saksi Silvia Pramudanti, } \\
\text { memberikan persetujuan kepada }\end{array}$ & $\begin{array}{l}\text { Herman Adi AW tidak } \\
\text { melakukan perintah dari aturan } \\
\text { tersebut dengan sebagaimana } \\
\text { mestinya, dimana berdasarkan } \\
\text { fakta-fakta yang terungkap } \\
\text { dipersidangan diketahui bahwa } \\
\text { Herman Adi AW yang telah } \\
\text { memberikan } \\
\text { pembayaran/pencairan dana atas }\end{array}$ \\
\hline $\begin{array}{l}\text { saksi Ladzuardi Thirin untuk } \\
\text { memberikan kompensasi berupa } \\
\text { komisi (fee) kepada rekanan yang } \\
\text { nama perusahaannya digunakan } \\
\text { untuk formalitas kegiatan, jelas } \\
\text { merupakan perbuatan yang telah }\end{array}$ & $\begin{array}{lrr}\text { paket pekerjaan } & \text { sebelum } \\
\text { pekerjaan tersebut } & \text { selesai } \\
\text { dilaksanakan } & \text { dalam pengertian } \\
\text { dana bagi } & \text { kegiatan } & \text { belum } \\
\text { tersedia, } & \text { sehingga } & \text { saksi } \\
\text { Ladzuardi } & \text { Thirin } & \text { dapat }\end{array}$ \\
\hline $\begin{array}{l}\text { menyalahgunakan kewenangan } \\
\text { yang ada padanya untuk tujuan } \\
\text { yang lain dari tujuan kewenangan } \\
\text { tersebut diberikan, dimana } \\
\text { sesuai dengan Surat Keputusan } \\
\text { Kepala Dinas Perindustrian dan }\end{array}$ & $\begin{array}{l}\text { mempergunakan uang hasil } \\
\text { pencairan untuk melakukan } \\
\text { pembelian barang-barang yang } \\
\text { diperlukan dalam pekerjaan } \\
\text { tersebut, oleh karenanya jelas } \\
\text { bahwa perbuatan Herman Adi AW }\end{array}$ \\
\hline $\begin{array}{l}\text { Perdagangan Nomor } \\
\text { 050/0080/2011 tanggal } 8 \text { Februari }\end{array}$ & $\begin{array}{l}\text { tersebut merupakan perbuatan } \\
\text { yang bertentangan dengan }\end{array}$ \\
\hline $\begin{array}{l}2011 \text { tentang Penunjukan Pejabat } \\
\text { Pembuat Komitmen dan Panitia } \\
\text { Pengadaan Barang dan Jasa }\end{array}$ & $\begin{array}{l}\text { ketentuan sebagaimana yang } \\
\text { dimaksudkan dalam Pasal } 21 \\
\text { Undang Undang Nomor } 1 \text { Tahun }\end{array}$ \\
\hline Dinas Perindustrian dan & 2014 tentang Perbendaharaan \\
\hline $\begin{array}{l}\text { Perdagangan Kabupaten Brebes } \\
\text { Tahun 2011, Herman Adi AW } \\
\text { telah menunjuk Panitia yang } \\
\text { diberikan tugas dan kewenangan } \\
\text { untuk melaksanakan kegiatan }\end{array}$ & $\begin{array}{l}\text { Negara, dan tidak mempedomani } \\
\text { ketentuan tentang pengelolaan } \\
\text { keuangan daerah secara tertib, } \\
\text { efektif, efisien, ekonomis, } \\
\text { transparan dan bertanggung }\end{array}$ \\
\hline
\end{tabular}




\section{7 | Jurnal Idea Hukum \\ Vol. 5 No. 1 Maret 2019 \\ Magister Hukum Fakultas Hukum Universitas Jenderal Soedirman}

jawab memperhatikan dengan

azas keadilan kepatutan dan

manfaat untuk masyarakat.

Perbuatan yang dilakukan

oleh Herman Adi AW

sebagaimana telah disebutkan di atas dilakukan oleh Herman Adi

AW tidak sesuai dengan kewenangan yang ada padanya, serta dilakukan untuk tujuan lain dari diberikannya kewenangan tersebut, maka perbuatan Herman Adi AW dalam kedudukannya sebagai Kepala Dinas Perindustrian dan Perdagangan tersebut menurut Pengadilan jelas merupakan perbuatan yang menyalahgunakan kewenangan yang ada padanya karena jabatan atau kedudukan.

Perbuatan penyalahgunaan yang dilakukan Herman Adi AW dalam "jabatan" atau "kedudukan" tertentu yaitu sebagai pengguna anggaran masuk dalam kategori penyalahgunaan wewenang (Detournement de Pouvoir). Dalam hukum administrasi Negara, setidaknya ada 3 (tiga) konsep Detournement de Pouvoir yang menjadi rujukan para ahli dan sarjana, yakni konsep dari Mariette Kobussen, Schrijvers dan Smeets, serta Philipus $M$. Hadjon. Mariette Kobussen dalam bukunya yang berjudul De
Vrijheid Van De Overheid mengembangkan konsep

Detournement de Pouvoir dengan tolok ukur atau parameter yaitu, asas spesialitas (specialiteitbeginsel). ${ }^{6}$

Menurut Schrijvers dan

Smeets, "Een bestuursorgaan mag en door de wet toegekende bevoegdheid allen gebruiken voor het doel dat de wetgever vor ogen had. Gebruik voor persoonlijke of andere doeleinden is dus verboden. Detournement de Pouvouir is dus handelen in strijd met het specialiteitbeginsel". (Organ Pemerintah hanya boleh menggunakan wewenang yang diberikan pembuat undangundang untuk suatu tujuan yang telah ditetapkan. Penggunaan wewenang untuk tujuan lain atau orang lain adalah dilarang. Dengan demikian, penyalahgunaan wewenang adalah melakukan tindakan yang bertentangan dengan asas spesialitas). ${ }^{7}$

Berdasarkan Pasal 17 ayat (1) UU 30 Tahun 2014 tentang Administrasi Pemerintahan menyatakan bahwa, Badan

6 Indriyanto Seno Adji, 2007, Korupsi Kebijakan Aparatur Negara dan Hukum Pidana, Diadit Media: Jakarta, hal. 26.

7 Ridwan H.R, 2011, Hukum Administrasi Negara, Edisi Revisi, Raja Grafindo Persada, Jakarta, hal. 382. 
$\begin{array}{lr}\text { dan/atau Pejabat } & \text { Pemerintahan } \\ \text { dilarang } & \text { menyalahgunakan } \\ \text { Wewenang. } & \text { Larangan } \\ \text { penyalahgunaan } & \text { wewenang } \\ \text { meliputi : } & \end{array}$

a. Larangan Melampaui Wewenang;

b. Larangan

Mencampuradukan

Wewenang; dan/atau

c. Bertindak Sewenangwenang.

Jika dikaitkan dengan ketentuan tersebut, perbuatan penyalahgunaan wewenang yang dilakukan Herman Adi AW merupakan dalam kategori larangan melampaui wewenang. Berdasarkan Pasal 18 ayat (1) UU 30 Tahun 2014 tentang Administrasi Pemerintahan menyatakan bahwa, Badan dan/atau Pejabat Pemerintahan dikategorikan melampaui Wewenang apabila Keputusan dan/atau Tindakan yang dilakukan melampaui masa jabatan atau batas waktu berlakunya Wewenang, melampaui batas wilayah berlakunya Wewenang; dan/atau bertentangan dengan ketentuan peraturan perundang-undangan.

\section{Pertanggungjawaban}

$\begin{array}{lr}\text { Hukum Pengguna } & \text { Anggaran Terhadap } \\ \text { Penyalahgunaan }\end{array}$

Wewenang Dalam

Pengadaan Barang di Kabupaten Brebes

Berdasarkan segi segi pertanggungjawaban tersebut, maka dapat digambarkan pertanggungjawaban berdasarkan analogi gambar sabagai berikut:

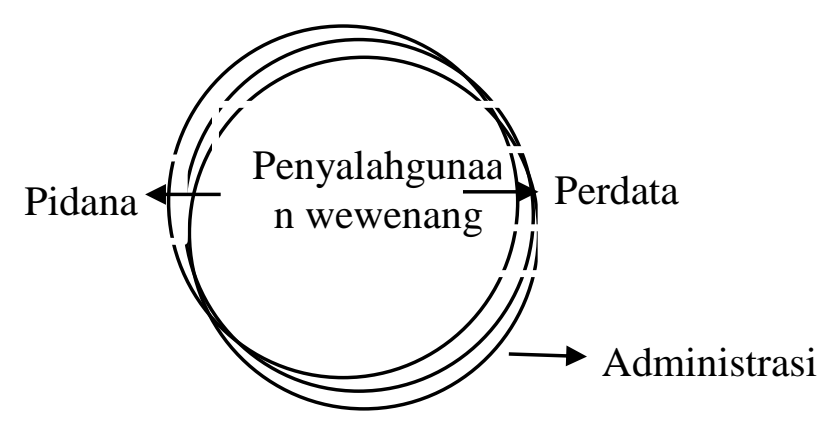

Perbuatan seorang pejabat pengguna anggaran sebagai Pegawai Negeri Sipil dalam suatu lingkup tugasnya dapat dibedakan atas tindakan perseorangan atau tindakan badan hukum (institusi kepegawaian), dalam lingkup tugasnya tersebut seorang PNS tidak dibenarkan untuk berbuat yang tidak wajar atau penyalahgunaan wewenang dan ini dipandang sebagai tindakan perseorangan secara pribadi yang harus dipertanggungjawabkan secara hukum baik pidana, perdata ataupun administrasi Negara (disiplin kepegawaian).

Dalam lingkungan PNS, guna menjamin tata tertib dan kelancaran pelaksanaan tugas pekerjaan telah dibuat suatu 
ketentuan tentang disiplin PNS

ketentuan tersebut didalam

Peraturan Pemerintah Nomor 53 tahun 2010 tentang Disiplin

Pegawai Negeri Sipil, dan ketentuan pelaksanaannya ditetapkan dalam surat Edaran Kepala Badan Administrasi Kepegawaian Negara No. 23/SE/1980 tahun 1980 dan PERKA No. 21 tahun 2010 tentang ketentuan pelaksanaan Peraturan Pemerintah Nomor 53 tahun 2010 tentang Disiplin PNS.

Berdasarkan Keputusan

Bupati Brebes No 887/080 Tahun 2014 terhitung mulai 24 Januari 2014 memberhentikan sementara dari jabatan Herman Adi AW dalam Kedudukannya selaku Kepala Dinas Perindustrian. Terhitung mulai tanggal 1 Februari 2014 kepada pegawai negeri tersebut diberikan gaji pokok sebesar Rp. 3.146 .000 (75\% x 4.195.200) ditambah dengan penghasilan lain yang sah berdasarkan peraturan perundang-undangan yang berlaku.

Selain

pertanggungjawaban

administrasi, pejabat yang melakukan penyalahgunaan wewenang dapat dikenai sanksi pertanggungjawaban perdata karena telah merugikan keuangan
Negara. Pasal 1366 KUHPerdata berbunyi:

Setiap orang tidak hanya
bertanggungjawab untuk
kerugian yang disebabkan
perbuatannya, tetapi juga
masuk kerugian yang
disebabkan karena
kelalaian atau kekurang
hati-hatian.

Perbuatan melawan hukum dalam bahasa Belanda disebut dengan onrechmatige daad dan dalam bahasa Inggris disebut tort. Kata tort itu sendiri sebenarnya hanya berarti salah (wrong). Akan tetapi, khususnya dalam bidang hukum, kata tort itu sendiri berkembang sedemikian rupa, sehingga berarti kesalahan perdata yang bukan berasal dari wanprestasi dalam suatu perjanjian kontrak. Jadi serupa dengan pengertian perbuatan melawan hukum disebut onrechmatige daad dalam sistem hukum Belanda atau di negaranegara Eropa Kontinental lainnya. Kata " tort " berasal dari kata latin "torquere " atau " tortus " dalam bahasa Perancis, seperti kata " wrong " berasal dari kata Perancis "wrung " yang berarti kesalahan atau kerugian (injury). Sehingga pada prinsipnya, tujuan dibentuknya suatu sistem hukum yang kemudian dikenal dengan 
perbuatan melawan hukum ini adalah untuk dapat mencapai seperti apa yang dikatakan dalam pribahasa bahasa Latin, yaitu juris praecepta sunt luxec, honestevivere, alterum non laedere, suum cuique tribuere (semboyan hukum adalah hidup secara jujur, tidak merugikan orang lain, dan memberikan orang lain haknya). ${ }^{8}$

Sebagaimana ditegaskan dalam Pasal 1365 KUHPerdata, dalam hal seseorang melakukan suatu Perbuatan Melawan Hukum maka dia berkewajiban membayar ganti rugi akan perbuatannya tersebut, hal yang berbeda dengan Tuntutan kerugian dalam Wanprestasi, dalam tuntutan Perbuatan Melawan Hukum tidak ada pengaturan yang jelas mengenai ganti kerugian tersebut namun sebagaimana diatur dalam Pasal 1371 ayat (2) KUH Perdata tersirat pedoman yang isinya; Juga penggantian kerugian ini dinilai menurut kedudukan dan kemampuan kedua belah pihak, dan menurut keadaan. Pedoman selanjutnya mengenai ganti kerugian dalam perbuatan melawan hukum.

${ }^{8}$ Rachmat Setiawan, 2002, Tinjauan Elementer Perbuatan Melawan Hukum, Alumni, Bandung, hal. 15
Pada kasus Herman Adi AW dalam Kedudukannya selaku Kepala Dinas Perindustrian, uang pengganti yang akan dibebankan kepada terdakwa sesuai dengan ketentuan Pasal 18 Undang Undang Nomor 31 Tahun 1999 tentang Pemberantasan Tindak Pidana Korupsi sebagaimana telah diubah dan ditambah dengan Undang-Undang Nomor 20 Tahun 2001 tentang Perubahan Atas Undang Undang Nomor 31 Tahun 1999 tentang Pemberantasan Tindak Pidana Korupsi adalah sebesar Rp.40.000.000,00 (empat puluh juta rupiah) sebagaimana tertuang dalam amar putusan ini, yang diperhitungkan dengan jumlah uang yang telah dikembalikan oleh Herman Adi AW.

Selain

pertanggungjawaban

administrasi, dan pertanggungjawaban hukum secara perdata, terdapat pula pertanggungjawaban pidana. Untuk membahas "penyalahgunaan kewenangan" dalam tindakan pemerintah yang berimplikasi pada tindak pidana korupsi maka kita perlu mengkaji Undang-Undang Nomor 31 Tahun 1999 jo. Undang-Undang Nomor 20 Tahun 2001 tentang 


\section{1 | Jurnal Idea Hukum \\ Vol. 5 No. 1 Maret 2019 \\ Magister Hukum Fakultas Hukum Universitas Jenderal Soedirman}

Pemberantasan Tindak Pidana

Korupsi, Pasal 3 yang berbunyi:

"Setiap orang yang dengan tujuan menguntungkan diri sendiri atau orang lain atau suatu korporasi, menyalahgunakan

kewenangan, kesempatan atau sarana yang ada padanya karena jabatan atau kedudukan yang dapat merugikan keuangan negara atau perekonomian negara, dipidana dengan pidana penjara seumur hidup atau pidana penjara paling singkat 1 (satu) tahun dan paling lama 20 (dua puluh) tahun dan/atau denda paling sedikit Rp50.000.000,00 (lima puluh juta rupiah) dan paling banyak Rp1.000.000.000,00 (satu miliar rupiah)".

Berdasarkan pertimbangan hukum hakim dalam Putusan Nomor

32/Pid.Sus/2014/PN.Tip.Smg.

disebutkan bahwa, perbuatan terdakwa telah memenuhi semua unsur tindak pidana dari pasal yang didakwakan oleh Penuntut Umum dalam dakwaan Subsidair yaitu melanggar Pasal 3 jo. Pasal 18 UU RI No. 31 Tahun 1999 tentang Pemberantasan Tindak Pidana Korupsi sebagaimana telah diubah dan ditambah dengan Undang-Undang RI Nomor 20 Tahun 2001 tentang Perubahan Atas UU RI Nomor 31 Tahun 1999 tentang Pemberantasan Tindak Pidana
Korupsi jo. Pasal 55 ayat (1) ke-1

KUHP;

Putusan

Nomor:

32/Pid.Sus/2014/PN.Tip.Smg. menyatakan terdakwa HERMAN ADI AW, SH. MH. Bin ROHADI, telah terbukti secara sah dan meyakinkan bersalah melakukan tindak pidana "Korupsi Secara Bersama-sama"; Majelis Hakim menjatuhkan pidana terhadap terdakwa HERMAN ADI AW, SH. $M H$. Bin ROHADI, oleh karena itu dengan pidana penjara selama 1 (satu) tahun dan 6 (enam) bulan, serta pidana denda sejumlah Rp. 50.000.000,00 (lima puluh juta rupiah), dengan ketentuan apabila Pidana Denda tersebut tidak dibayar, maka diganti dengan Pidana Kurungan selama 2 (dua) bulan.

Setelah ada putusan hakim Nomor

32/Pid.Sus/2014/PN.Tip.Smg.

menyatakan terdakwa HERMAN ADI AW, SH. MH. Bin ROHADI, telah terbukti secara sah dan meyakinkan bersalah melakukan tindak pidana "Korupsi Secara Bersama-sama”, Pemerintah Kabupaten Brebes juga menjatuhkan sanksi administrasi kembali dengan mengeluarkan Surat Keputusan Bupati Brebes Nomor 887/276 Tahun 2014 tentang Pemberhentian dengan 
Tidak Hormat kepada Pegawai Negeri Sipil An. HERMAN ADI AW, SH. MH. Terhitung sejak tanggal 19 Juni 2014 kepada Pegawai Negeri Sipil tersebut diberhentikan dengan tidak hormat tanpa hak pensiun.

\section{G. Simpulan Dan Saran}

1. Simpulan

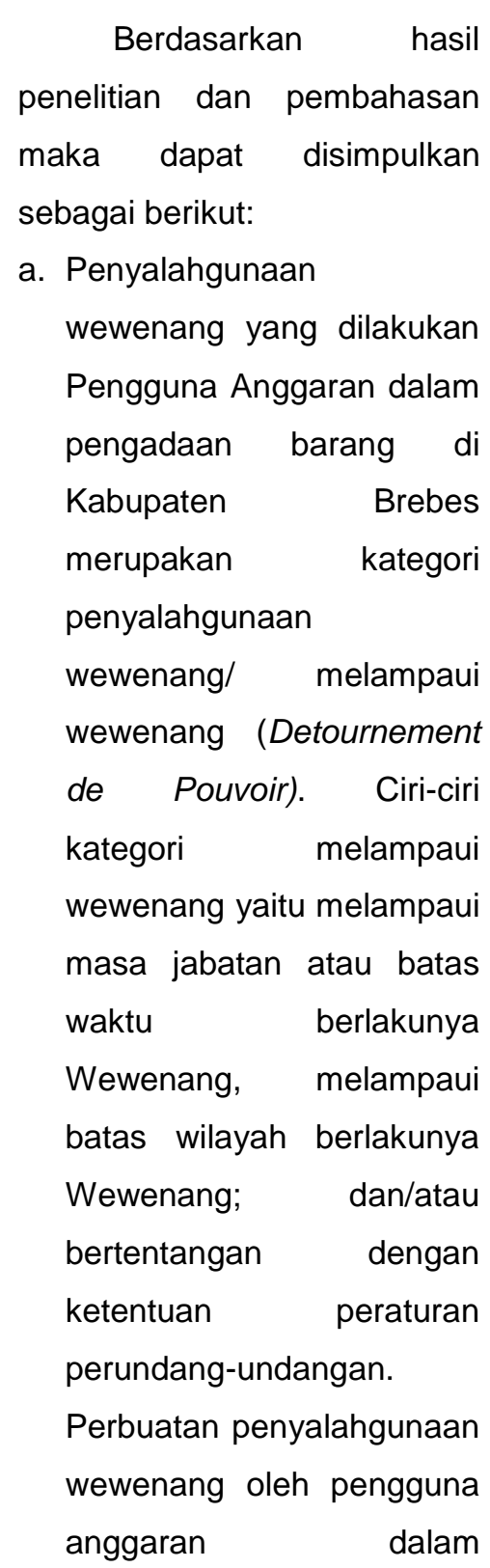

pengadaan barang di
Kabupaten Brebes telah
bertentangan
ketentuan dengan

perundang-undangan yang

secara spesifik diatur dalam Pasal 5 dan Pasal 6

Perpres Nomor 54 Tahun 2010 beserta

Perubahannya khususnya prinsip transparan, bersaing dan akuntabel serta telah melanggar etika pengadaan. Selain itu, Perbuatan penyalahgunaan wewenang yang dilakukan Herman Adi AW selaku pengguna anggaran juga bertentangan dengan ketentuan Pasal 21 Undang Undang Nomor 1 Tahun 2014 tentang Perbendaharaan Negara. Penyalahgunaan wewenang yang dilakukan oleh Pengguna Anggaran juga merupakan perbuatan melawan hukum dalam arti yang khusus (spesies) yakni merupakan bentuk dari penyalahgunaan wewenang karena kedudukan atau jabatan yang diembannya dan telah menimbulkan kerugian negara, hal itu sesuai dengan Pasal 3 Undang 


\section{3 | Jurnal Idea Hukum \\ Vol. 5 No. 1 Maret 2019 \\ Magister Hukum Fakultas Hukum Universitas Jenderal Soedirman}

\author{
Undang Nomor 31 Tahun \\ 1999 tentang \\ Pemberantasan Tindak \\ Pidana Korupsi Jo Undang \\ Undang Nomor 20 Tahun \\ 2001 tentang Perubahan \\ atas Undang Undang \\ Nomor 31 Tahun 1999 \\ tentang Pemberantasan \\ Tindak Pidana Korupsi. \\ b. Pertanggungjawaban \\ hukum yang dibebankan \\ kepada Pengguna \\ Anggaran yang melakukan \\ penyalahgunaan \\ wewenang dalam \\ pengadaan barang di \\ Kabupaten Brebes yaitu : \\ 1) Sanksi Pidana \\ Berdasarkan \\ pertanggungjawaban \\ pidana penyalahgunaan \\ wewenang diatur dalam \\ Pasal 3 Undang-Undang \\ Nomor 31 Tahun 1999 \\ tentang Pemberantasan \\ Tindak Pidana Korupsi \\ Jo Undang Undang \\ Nomor 20 Tahun 2001 \\ tentang Perubahan atas \\ Undang Undang Nomor \\ 31 Tahun 1999 tentang \\ Pemberantasan Tindak \\ Pidana Korupsi. \\ 2) Sanksi Perdata \\ Berdasarkan \\ pertanggungjawaban
}

perdata Pengguna

Anggaran wajib

mengembalikan ganti

kerugian.

3) Sanksi Administrasi

Berdasarkan segi administrasi, perbuatan

seorang pejabat

pengguna anggaran

sebagai Pegawai Negeri

Sipil dalam suatu

lingkup tugasnya dapat dibedakan atas tindakan

perseorangan atau

tindakan badan hukum

(instuitusi

kepegawaian), dalam

lingkup tugasnya

tersebut seorang PNS

tidak dibenarkan untuk

berbuat yang tidak wajar

atau penyalahgunaan

wewenang dan ini

dipandang sebagai

tindakan perseorangan

secara pribadi yang

harus

dipertanggungjawabkan

secara hukum. Dalam

lingkungan PNS, guna

menjamin tata tertib dan

kelancaran pelaksanaan

tugas pekerjaan telah

dibuat suatu ketentuan

tentang disiplin PNS,

ketentuan tersebut

didalam Peraturan 
Pemerintah Nomor 53

tahun 2010 tentang

Disiplin Pegawai Negeri

Sipil, dan ketentuan

pelaksanaannya yang

ditetapkan dalam surat

Edaran Kepala Badan

Administrasi

Kepegawaian Negara

No. 23/SE/1980 tahun

1980 dan PERKA No.

21 tahun 2010 tentang

ketentuan pelaksanaan

Peraturan Pemerintah

Nomor 53 tahun 2010

tentang Disiplin PNS.

Menindaklanjuti hal

tersebut, Pemerintah

Kabupaten Brebes

mengeluarkan Surat

Keputusan Bupati

Brebes tentang

Pemberhentian

Sementara dari Jabatan

dan tahap selanjutnya

setelah ada Putusan

Hakim yang

menyatakan terdakwa

Pengguna Anggaran,

telah terbukti secara sah

dan meyakinkan

bersalah melakukan

tindak pidana "Korupsi

Secara Bersama-sama",

Pemerintah Kabupaten

Brebes mengeluarkan

Surat Keputusan Bupati
Brebes

tentang

Pemberhentian dengan

Tidak Hormat kepada

Pegawai Negeri Sipil

tersebut, diberhentikan

dengan tidak hormat

tanpa hak pensiun.

\section{Saran}

a. Perlu dilakukan

pengawasan dan

pendampingan oleh

Inspektorat Kabupaten

Brebes secara rutin setiap

tahun sekali terhadap

kegiatan pengadaan

barang dan jasa

khususnya pengadaan

langsung pada setiap

SKPD, sehingga dapat

mengurangi potensi

terjadinya

penyalahgunaan

wewenang.

b. Sebagai langkah untuk mengurangi potensi

terjadinya

penyalahgunaan

wewenang dalam

pengadaan langsung,

Pemerintah Kabupaten

Brebes telah membuat aplikasi SITAMPAN.

Diharapkan setiap SKPD dapat memanfaatkan aplikasi tersebut dengan optimal sehingga 


\section{5 | Jurnal Idea Hukum}

Vol. 5 No. 1 Maret 2019

Magister Hukum Fakultas Hukum Universitas Jenderal Soedirman

kesalahan administrasi

dapat dihindari.

c. Apabila terdapat temuan hasil pemeriksaan oleh Inspektorat Kabupaten Brebes, diharapkan SKPD segera menindaklanjuti hasil temuan tersebut dalam jangka waktu 60 (enam Puluh) hari agar tidak beralih ke aparat penegak hukum.

d. Pertanggungjawaban pidana terhadap pengadaan barang dan jasa perlu dilaksanakan sosialisasi dari LKPP sehingga timbul pemahaman yang benar tentang pengadaan barang dan jasa untuk menghindari terjadinya penyalahgunaan wewenang terhadap pengadaan barang dan jasa pemerintah daerah.

\section{DAFTAR PUSTAKA}

Adji, Indriyanto Seno. 2007. Korupsi Kebijakan Aparatur Negara dan Hukum Pidana. Diadit Media: Jakarta.

Bell, John. dkk. 1998. Principles of French Law. Oxford University Press. Egland.
Hadjon, Philipus M. 2005 Pengantar Administrasi Negara Indonesia Penerbit Gajah Mada University Press Yogyakarta..

H.R, Ridwan. 2011. Hukum Administrasi Negara. Edisi Revisi. Raja Grafindo Persada. Jakarta.

Marbun, SF. 2001. Eksistensi Asas-Asas Umum Penyelenggaraan Pemerintahan Yang Layak Dalam Menjelmakan Pemerintahan Yang Baik dan Bersih di Indonesia. Disertasi Unpad. Bandung.

Setiawan, Rachmat. 2002. Tinjauan Elementer Perbuatan Melawan Hukum. Alumni. Bandung. 